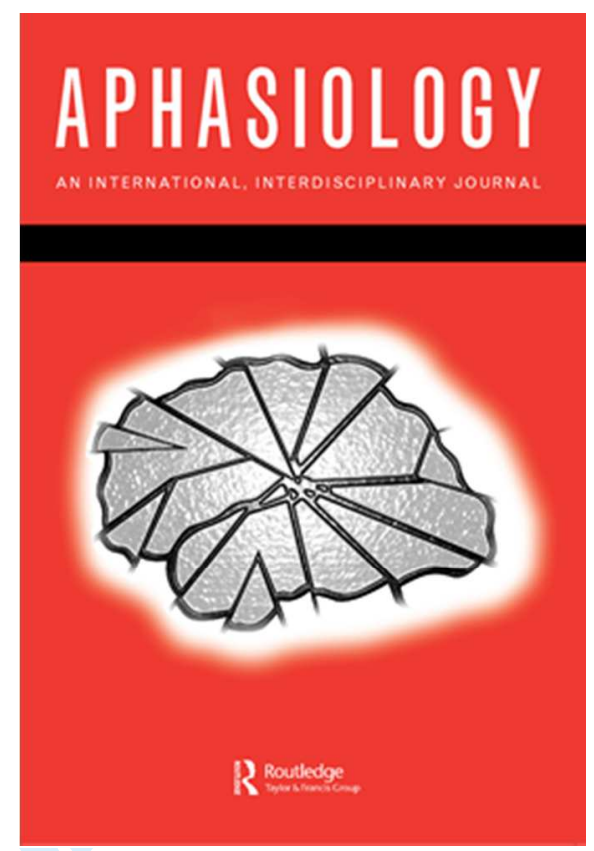

\title{
A novel treatment targeting the exchange of new information within storytelling for people with non-fluent aphasia and their partners
}

\begin{tabular}{|r|l|}
\hline Journal: & Aphasiology \\
\hline Manuscript ID: & Draft \\
\hline Manuscript Type: & Paper \\
\hline Date Submitted by the Author: & n/a \\
\hline Complete List of Authors: & $\begin{array}{l}\text { Carragher, Marcella; East Lancashire Hospitals Trust, Speech and language } \\
\text { therapy }\end{array}$ \\
\hline Keywords: & $\begin{array}{l}\text { non-fluent aphasia, interactive storytelling, information exchange, } \\
\text { generalisation }\end{array}$ \\
\hline &
\end{tabular}

\section{SCHOLARONE" \\ Manuscripts}


A novel treatment targeting the exchange of new information within storytelling for people with non-fluent aphasia and their partners

\author{
Marcella CARRAGHER ${ }^{\mathrm{a}}$
}

Karen $\mathrm{SAGE}^{\mathrm{b}}$

Paul CONROY

\title{
Word count: 6,519
}

Acknowledgements: This work is supported by a Research Bursary from the Stroke Association (TSA JRTF 2009/01). We are grateful to the participants with aphasia and their families for their time, effort and enthusiasm in taking part in the study. This work would not have been possible without the support of speech and language therapists who cascaded information about the study to potential participants. 


\begin{abstract}
Background: Therapy for people with aphasia (PWA) can encompass a wide range of aims and methodologies, from targeting the linguistic impairment, to strategic compensation to optimise communication, interaction and vocational rehabilitation. Across treatment type, one unifying area of interest relates to the generalisation of behaviours targeted in therapy to untrained tasks and contexts, particularly those related to everyday communication. Therefore, aphasia rehabilitation ultimately has a social goal of optimising the communication of the person with aphasia (PWA) within their typical environment. One important aspect of everyday communication relates to conveying new information and telling anecdotes/stories. Measures of transactional success in storytelling have previously demonstrated reliability and validity as an analytical method.
\end{abstract}

Aim: The study aimed to extend previous work on transactional success in storytelling to a programme of therapy targeting both the PWA and the communication partner $(\mathrm{CP})$.

Methods and procedures: Four participants with chronic non-fluent aphasia and their CPs were recruited and a novel dual-focus treatment was administered. For the PWA, therapy targeted storytelling using the principles of 'thinking for speaking' and story grammar. For the partner, therapy drew on the principles of conversation coaching to increase facilitative behaviours within storytelling to aid the construction of shared understanding. Quantitative measures were used to investigate effects of treatment in novel storytelling tasks for the group and within a single case study. 
Outcomes and results: There were numerical gains in information exchange for three of four couples, where the conversation partner displayed improved understanding of the PWQ's story, and a decrease for one couple. Evidence of likely direct effects of therapy across both simple and complex storytelling was consistent for two of the four couples. The single case study suggested change consistent with the aims of the treatment programme.

Conclusions: The method of dual-focused therapy and outcome measurement outlined in this paper offers promise for targeting an important aspect of everyday communication in a standardised task. Potential for future investigation is discussed. 
Key words: non-fluent aphasia; interactive storytelling; information exchange; generalisation

1

2

3

4

5

6

10

10

11

12

13

14

15

16

17

18

19

20

21

22

23

24

25

26

27

28

29

30

31

32

33

34

35

36

37

38

39

40

41

42

43

44

45

46

47

48

49

50

51

52

53

54

55

56

57

58

59

60

URL: http://mc.manuscriptcentral.com/paph Email: c.f.s.code@exeter.ac.uk 


\section{Introduction}

Therapy for people with aphasia (PWA) encompasses a wide range of aims and methodologies, from targeting the linguistic impairment (Carragher, Sage, \& Conroy, 2013), communication compensation (Hopper, Holland, \& Rewega, 2002), interaction (Beeke, Maxim, Best, \& Cooper, 2011) and vocational rehabilitation (Morris, Franklin, Menger, \& GD, 2011). Across these treatment approaches, one unifying area of interest relates to the generalisation of behaviours targeted in therapy to untrained tasks and contexts, particularly those related to everyday communication. But how should we measure the effects of treatment on everyday communication?

One option relates to the collection and analysis of naturally occurring conversation data. Certainly, conversation has been observed to be the most common type of daily communication for PWA and matched healthy control participants (Davidson, Worrall, \& Hickson, 2003). Yet capturing evidence of quantitative change in conversation has proved difficult, not least because no standardised, quantitative measure of conversation exists (Beeke et al., 2011). Moreover, the high demands of time and skill needed to carry out qualitative analysis of conversation present challenges for service delivery in busy clinical settings (Bradley \& Douglas, 2008).

From a broader perspective, everyday communication is multifaceted encompassing both interaction and transaction (Davidson et al., 2003). One solution might be to use the naturally occurring transactional opportunities in everyday communication to target treatment and to capture evidence of change. Transactional communication encompasses various types of discourse genre - conversation, expository, procedural (Armstrong, 2000). Within transactional communication, conveying new information 
has central role. It is problematic to measures transactional success within conversation for a number of reasons: lack of external criteria on which to judge transactional success (Ramsberger \& Rende, 2002); potential lack of clarity regarding a speaker's target word or meaning (Armstrong, 2000); potential for a dissociation between the information expressed by the speaker and how this is understood by the conversation partner (Ramsberger \& Rende, 2002); as well as the opportunity for speakers to draw on shared knowledge which may not be expressed explicitly. Thus, in order to measure transactional success, it is necessary to use a context that shares similarities to conversation but, crucially, offers potential for externally-set criteria and standardisation. One such context is storytelling, which offers a broad scope in which to base outcome measurement and treatment:

- Social perspective: storytelling is a means of self-expression (McAdams, 2001), displaying and experiencing an evolving identity (Bierren, Kenyon, Ruth, Shroots, \& Svendson, 1996), engaging with others and passing on life experience (Randall, 2001). Storytelling is a way in which we make sense of the world, particularly during challenging life transitions and traumatic events (Riessman, 1993).

- Clinically valid: PWA engage in significantly less storytelling in daily life compared to healthy controls (Davidson et al., 2003). Thus the powerful benefits of storytelling as a way of engaging with others and as a means of coping are beyond the reach of a population who could benefit from this social activity. This suggests that storytelling is a clinically valid context for treatment and outcome measurement.

- Linguistic perspective: production of narrative or storytelling encompasses skills of macrolinguistics (e.g., the planning and sequencing of information 
within a structured framework and tailored towards the listener's perspective) and mircolinguistics (i.e., semantic and syntactic aspects of production) which resonate throughout many language production activities in daily life (Whitworth, 2010). There is growing evidence from therapy literature of the need to explicitly support PWA to generalise the skills developed within therapy sessions to everyday communication (Whitworth, 2010; Carragher, Sage, \& Conroy, 2013).

- Methodological rigour: as an outcome measure, storytelling offers several advantages including replicability, the potential for standardisation across participants, and an opportunity for comparison of performances across individuals (Ramsberger \& Rende, 2002; Ramsberger \& Menn, 2003).

- Validity: like everyday conversation, interactive storytelling captures evidence of speakers' turn-taking and negotiating the 'point' of the story (Norrick, 2000). Furthermore, narrative stimuli are rich with options as to what will be communicated. This presents choices to the PWA regarding expression of story events through verbal and/or nonverbal means, compared to more traditional language assessment which places constraints on possible linguistic responses and syntactic constructions (Hernandez-Sacristan \& Rosell-Clari, 2009).

The current study builds on work by Ramsberger and colleagues (Ramsberger \& Rende, 2002; Ramsberger \& Menn, 2003) by extending interactive storytelling to a therapy task. The paper outlines the novel approach of 'Interactive Storytelling Therapy', a standardised approach to shaping and enhancing the exchange of new information between PWA and their CPs within a storytelling context. Interactive 
Storytelling Therapy establishes storytelling as a shared communicative activity between speakers. In this way, it differs from narrative therapy (e.g., Whitworth, 2010) which focuses solely on the production of the PWA, omitting features of storytelling such as to whom the story is addressed and how the teller and the recipient interact to achieve mutual understanding (Goodwin, 1995). Uniquely, Interactive Storytelling Therapy targets and optimises the co-construction of stories by two people (Bronken, Kirkevold, Martinsen, \& Kvigne, 2012), a feature that may be especially important when one speaker has aphasia. Therapy consists of a dualfocus targeting both the PWA and the CP in order to optimise the exchange of new information. By using video clips to stimulate storytelling, the therapy approach offers a method of standardising treatment sessions whilst maintaining features of everyday interaction, e.g., the $\mathrm{CP}$ is blind to the video content, simulating a real-life communicative situation in which the PWA is imparting new information. The CP's understanding of the story is analysed to quantify the collaborative success of the PWA and the CP in negotiating shared understanding (transactional success) within a storytelling context (e.g., Ramsberger \& Rende, 2002).

\section{Aims of the study}

The current study aimed to investigate the effect of dual-focused therapy targeting interactive storytelling between a speaker with aphasia and his/her CP. Specifically, the study aimed to answer the following questions:

- What is the effect of therapy for couples exchanging new information within interactive storytelling? 
- What specific behaviours drive the changes in the quantity of new information exchanged for one couple?

\section{Method}

\subsection{Participants}

Following ethical approval via standard UK protocols (NHS IRAS system), four participants were recruited. This study formed the third in a series of therapy studies targeting incremental levels of language output in individuals with non-fluent aphasia. As part of a larger group of participants $(\mathrm{N}=9)$, these four participants had taken part in previous therapy studies targeting verb retrieval (Carragher et al., 2013) and syntactic construction (Carragher, Sage, \& Conroy, submitted). All participants presented with stroke-induced chronic non-fluent aphasia. Presentation of non-fluent aphasia was confirmed on the basis of converging evidence from clinical consensus, the results of standardised lexical retrieval assessment (as indicated by a clinical score on the Boston Naming Test) and impaired use of grammatical markers and syntactic structures in picture description (Goodglass, Kaplan, \& Barresi, 2001). Participants were at least 6 months post-onset, reducing the likelihood of further spontaneous recovery. As apraxia of speech often co-occurs with non-fluent aphasia (McNeil, Robin, \& Schmidt, 2008), presence of apraxic errors did not form part of the exclusion criteria. Inter-participant variation existed for time post-onset, ranging from 26 months to 80 months (mean: 51.5, St Dev. 27.5). The participants ranged in age from 38 - 70 years (mean: 59.5, St Dev. 14.5); Table 1 provides background information on the four participants with aphasia. In each case, the conversation partner was the PWA's husband or wife, had known the PWA prior to the stroke and 
had no history of neurological impairment. Throughout the paper, the participants with aphasia are referred to using initials, while conversation partners are given pseudonyms.

Table 1 about here

\subsection{Background assessment}

Inter-participant variation existed for severity: noun naming (Boston Naming Test, Goodglass et al., 2001) ranged from 16 - 36 from a maximum score of sixty (mean: 26.3, St Dev. 10.0); verb naming (Druks \& Masterson, The Object Action Naming Battery, 2000) ranged from 30.5 - 59 from a maximum score of 100 (mean: 44.3, St Dev. 11.7). Further details of the participants and their performance on a battery of linguistic and cognitive assessments are provided in Carragher et al. (2013).

\subsection{Assessment stimuli}

Pre- and post-therapy assessment consisted of interactive storytelling in response to video stimuli. At each time point, the PWA watched a video clip in the absence of the $\mathrm{CP}$; the $\mathrm{CP}$ then returned to the room and the PWA recounted the story. The only instructions issued to the CP was that the PWA had viewed a video clip, they were asked to find out what happened in the clip and that they would later report their interpretation of it to the researcher. Participants were not instructed to use any particular interactional devices (e.g., making guesses, drawing). Assessment stimuli included a simple video narrative and a complex video narrative. Drawing on Weinrich, McCall, Boser and Virata's criteria (2002), simple narratives were defined as video clips that involved only 1-2 actors, 1-2 complicating actions and a resolution; 
complex narratives were defined as video clips that involved more than 2 actors, 4 complicating actions and a resolution. Data collected from control participants $(\mathrm{N}=8)$ were used to distinguish simple narrative video material from complex narrative material (see 'Outcome measures' for more details on the collection and analysis of control data).

Assessment stimuli at both time-points consisted of 'Mr Bean'1 DVD footage. These video clips were chosen for their minimal spoken language content, thereby minimising the linguistic scaffolding available to the PWA in constructing the story. Cultural familiarity was a further factor in the selection of assessment stimuli - ' $\mathrm{Mr}$ Bean' clips contain highly familiar/imageable concepts and humorous content which is watched by adults as well as children. Similar to real-life communication, once the referent of Mr Bean had been established, the $\mathrm{CP}$ would have access to some shared knowledge about the protagonist (Ramsberger and Menn, 2003, Ramsberger and Rende, 2002). In order to minimise the effects of memory or practice, novel stimuli were used across pre- and post-therapy assessment although they were based on the same comic character. CPs were not told in advance the subject or nature of the narrative topics in the assessment video stimuli.

\subsection{Therapy stimuli}

For the therapy sessions, video clips were sourced from YouTube and viewed by PWA using an iPad. The Mr Bean video footage was not used within therapy sessions but reserved for pre- and post-therapy assessment only. Video clips were selected for

\footnotetext{
${ }^{1} \mathrm{Mr}$ Bean is a socially inept character who gets himself into embarrassing, comic scenarios, such as becoming frightened in front of others on a high diving board in a swimming pool.
} 
their interesting and newsworthy nature; they were often funny and therefore motivating for the couple to discuss; and they involved minimal or no use of language. As the PWA presented across a range of aphasic severity, it was important that the video clips used within the therapy sessions were capable of challenging the higher-level participants whilst not alienating those participants with less linguistic and communicative abilities. Therefore, selection of the therapy stimuli aired on the side of complex narratives. Within the therapy sessions, the higher-level participants were encouraged to include details within their story construction whilst the participants with a more severe aphasic impairment were encouraged to construct a more striped-back story structure.

Outlined below are the YouTube clips selected for the therapy sessions, the length of each clip and their current web address:

Seaplane fishing (00:54) http://www.youtube.com/watch?v=iY6AWs2QMbM

Pixar Geri’s game (03:50) http://www.youtube.com/watch?v=9IYRC7g2ICg

Pixar Pigeons (02:40) http://www.youtube.com/watch?v=oIlIVFBBbNw

Pixar For the birds (03:00) http://www.youtube.com/watch?v=VkuBIrdi6eE

French clip (01:52) http://www.youtube.com/watch?v=3xAE6gjvQ7Q

\subsection{Overview of Interactive Storytelling Therapy sessions}

Participants received six therapy sessions of approximately 1.5 hours, administered once a week. Within each session, up to 45 minutes was dedicated to working with the PWA, up to 30 minutes to working with the $\mathrm{CP}$, and the remainder of the session used for video feedback and discussion with the couple. The first therapy session focused on reflecting on current storytelling behaviours before targeting these 
behaviours in subsequent practical sessions (sessions 2-6). Figure 1 outlines the focus of therapy across sessions.

Figure 1 about here

Session 1: reflection and goal-setting

The first treatment session focused on encouraging the PWA and their partner to reflect on recorded the baseline storytelling data and to begin to increase their awareness of various strategies and choices evident within their interactions. Video feedback was used to facilitate discussion of the consequences of specific behaviours seen in the data. These included: strategies used by the PWA to convey events; strategies used by the CP to clarify information or elicit further explanation; displays of negative emotion such as frustration; alternatives to strategies seen in the video data; and, more broadly, sharing of the communicative burden and the overall effectiveness/success of the interaction. Couples were also encouraged to extend their reflections beyond the recorded interactive storytelling to consider their everyday conversations. During this initial session, therapy goals specific to each couple were suggested, based on analysis of pre-therapy interactive storytelling (see Appendix 2). The goals were given brief descriptive, mnemonic labels (e.g., 'Drip drip' and 'Pinpoint' - see Appendix 2 for definitions) to facilitate participants to remember their individual goals and also to aid discussion of specific strategies within the therapy sessions. For the PWA, therapy goals related to components of story grammar (Rumelhart, 1975), such as introducing key referents, while for the CP therapy goals related to repairing breakdowns in understanding. 


\section{Practical sessions $2-6$ : PWA}

This part of the therapy drew upon the principles of thinking for speaking (Marshall, 2009) and story grammar (Rumelhart, 1975). The practical sessions began with the PWA viewing a video clip in the absence of their partner (see Figure 1). The video clip was repeated as often as requested (participants usually requested a maximum of three repeated viewings). The researcher facilitated the PWA to segment the narrative into main events, broadly conceptualised as the beginning, middle and end sections of the story. Where relevant, the PWA was prompted to begin by introducing the story ('Set the scene' goal) by stating the main referent as well as other contextual information such as location or tone of the story (e.g., funny, sad). Throughout this process, the PWA was supported in his/her conceptualisation of the story through a visual record; the researcher used this to record the on-going construction of the story by writing down words/phrases produced by the PWA and using drawing to depict gesture. The visual record served as a useful anchor by which the PWA could monitor their progression as they constructed the story.

Having established the main referent of the story, the PWA was prompted to think about what happened next in segments (corresponding to the 'Chunk it up' and 'Drip drip' goals). This involved describing key information and actions relating to the main referent. The PWA was encouraged to produce an agent-verb construction, with the verb produced verbally or through gesture, writing or drawing. The aim was to optimise (rather than correct) participants' output; therefore, any prompts or modelling provided by the researcher were carefully built on the participant's original output. For example, if the PWA gestured 'running', the researcher prompted "Who?" followed by the gesture, with the aim of prompting the PWA to produce a more 
contentful construction incorporating both verbal and nonverbal output (related to the 'Show and Tell' goal). If the PWA produced a content word in isolation (e.g., "hungry"), the researcher used wh-questions (e.g., "who is hungry?”) and modelling (e.g., "bird hungry") to facilitate the PWA's production of argument structure. In line with a previous therapy study (Carragher, Sage, \& Conroy, submitted), all modelling of syntactic constructions involved morphologically reduced structures. The PWA was also facilitated to use direct reported speech (Hengst, Frame, Neuman-Stritzel, \& Gannaway, 2005) to depict characters' reactions within the story and to produce evaluative comments in grammatically simplified ways.

As the PWA progressed through the telling of each episode within the story, the segmentation of the story was reinforced visually through the use of the visual record, i.e., clearly marking the first, second, third, fourth etc. episodes of the story. This process was repeated until the complete story had been discussed and sketched out in the visual record. Throughout the story construction, the PWA was prompted to think selectively in terms of what details to include or omit from the story to ultimately facilitate their partner's comprehension of the story. In particular, the PWA was encouraged to consider whether a particular event or detail was key to understanding the story or more peripheral ${ }^{2}$.

By the end of this part of the session, the participant had produced the story three times in total, with incremental withdrawal of support from the researcher:

1. During the first telling, the PWA was maximally supported by the researcher to segment the story into events, to prioritise establishing key referents and to

\footnotetext{
${ }^{2}$ Issue of selectivity raised by Marshall and Cairns (2005)
} 
combine verbal output with gesture, drawing and writing. The researcher kept a visual record of the story which included key words, phrases and drawings.

2. In the second telling, the PWA was prompted to use the visual record to construct the story. Moderate support was given to remind the participants about the strategies discussed and developed during the first story telling. Also, at this stage, participants were facilitated to link together the various events within the story either verbally (e.g., "and then") or nonverbally (e.g., using gestures or fingers to indicate first, second, third, etc.).

3. During the third telling of the story, the visual record was removed and participants encouraged to construct the story independently, with the researcher providing feedback or requesting clarification where necessary.

The aim here was not to foster rote-learning of a particular story. Rather, the approach was to gradually withdraw support and to encourage independent use of key strategies to support the PWA in constructing the story in an optimal, coherent manner with regard to the sequence of ideas and relevant information.

Practical sessions 2-6: CPs

The CP then re-joined the therapy session in order to discuss the video clip with their partner with aphasia. At this point, the CP became the focus of therapy intervention (see Figure 1). Therapy sessions were video recorded with the participants' consent in order to facilitate later reflection (see next section). The researcher prompted the $\mathrm{CP}$ to recall the therapy goals agreed at the start of the intervention; as therapy progressed over a number of weeks, this discussion expanded to include topics that had arisen in earlier sessions. As the couple began to discuss the story, the researcher intervened on a needs-basis when a trouble source arose that the CP struggled to resolve. For 
example, the researcher offered a diagnosis of the problem (i.e., relating to a lexical search, confusion regarding a referent, or more meta-interactional issue regarding which part of the story was currently being discussed) and facilitated the CP to select one of the targeted goal behaviours to employ, e.g., 'Move along' or 'Stop and check' (see Appendix 2). If the CP struggled to select a strategy, the researcher suggested an appropriate strategy and modelled this behaviour as needed. The researcher did not intervene if the PWA omitted important details of the story or confirmed details about the story that were incorrect; the goal of therapy related to the exchange and negotiation of information between the couples rather than conveying specific details.

Practical sessions 2 - 6: the couple

Once the couple had finished discussing the story, the CP watched the target YouTube video clip and then together the couple viewed the video recording of them discussing the story (Figure 1, column 2). This enabled both the PWA and CP to evaluate off-line the strategies employed within the task. Discussion focused on the agreed goals for each individual; where relevant, discussion included any novel issues that had arisen during the session and goals were agreed for each couple to focus on in the homework task and in the subsequent therapy session.

\subsection{Outcome measures}

Outcome measurement focused on transactional success (i.e., exchange of new information) as reflected by the CP's interpretation of the story in comparison to control data. Control participants $(\mathrm{N}=8)$ viewed the $\mathrm{Mr}$ Bean video clips (as used in pre- and post-therapy assessment) and were asked to describe what happened. The control participants were non-language impaired, native English speakers. They were 
not matched to the participants with aphasia in the current study but represented a varied sample with respect to age (mean: 42 years old; range: 17 - 64), years of fulltime education (mean: 16 years; range: $11-21$ ) and gender (four male, four female). The control participants' descriptions of the Mr Bean video clips varied regarding quantity of description as well as the details provided (e.g., one control participant described Mr Bean driving a yellow car, another described Mr Bean driving a yellow Mini, while another simply reported Mr Bean drove into a carpark and omitted any details relating to the car). In order to distil the descriptions across the control participants to the core story components, written transcripts of the control participants' descriptions were analysed for the most commonly reported content words. Those content words that were reported by at least $50 \%$ of control participants were interpreted as forming essential components of the target story. Thus, content words that were produced by at least $50 \%$ of the control participants were labelled 'salient content words'. In this way, the control data provided a maximum score for each Mr Bean video clip. These 'salient' content words were used to develop model narratives for each clip consisting of the crucial parts of story structure, i.e., setting, complicating actions and resolution (Labov, 1972). The target components for each assessment video clip are shown in the shaded columns in Appendix 3.

For the pre- and post-therapy assessment stimuli, written transcripts of the CPs' retelling of each story were compared to the salient content words from the control data. A similar measure of transactional success in storytelling had demonstrated high validity and reliability as a method of analysis (Ramsberger \& Rende, 2002; Ramsberger \& Menn, 2003). 


\subsection{Data analysis}

The CPs' retelling of each assessment story was scored in comparison to the control data (see Appendix 3 for the maximum score achievable for each assessment stimulus). Points were awarded for each content word the CP produced which was similar to the salient words produced by control participants for the same video clip. In this way, CPs were credited only for that information that was deemed essential across control participants. Scoring the CPs' retelling of the assessment stimuli on the basis of alignment with the subset of content words most frequently produced by the control participants provided a quantitative measure of effects of therapy (see Appendix 3).

Although the focus of therapy included both the PWA as well as the CP, there were a number of reasons to focus the analysis solely on the partner. Beeke ar al. (2011) point out that "the sequential nature of turn taking in conversation means that they [the behaviours of the PWA and partner] are inextricably intertwined" (p.227). Therefore, it might be artificial to attempt to categorically separate the behaviours of speakers' changes (e.g., into the behaviour of the CP and the PWA). Furthermore, therapy ultimately targeted the exchange of new information. The CPs' retelling of the video clip encspsulates the sum of the PWA's ability to convey novel information as well as how the CP collaborated in the storytelling in order to make sense of the PWA's storytelling is. In this way, the CP's retelling of the story acts as an objective, quantifiable, catch-all representation of both the contributions of the PWA and the CP in negotiating and finding mutual understanding within the context of new information exchange. Thus, the complex and multifaceted nature of the therapy is crystallised into one concise quantitative outcome measure. 


\section{Results}

4.1 What is the effect of therapy for couples exchanging new information within interactive storytelling?

Using data from control participants, it was possible to segment each assessment narrative into distinct story segments, with a core group of target content words within each segment. As described above, these target content words represented those most frequently reported by control participants. In the CP data, points were awarded for each content word that was similar to those content words most frequently produced across control participants (see Appendix 3). Following therapy, content word analysis revealed numerical improvements for three CPs on the simple narrative ('Peter', 'Paula' and 'Noel') and for two CPs on the complex narrative (Peter and Paula); see Table 2. One partner ('Eve') demonstrated a decrease in the number of salient content words reported after therapy.

Table 2 about here

Given the inherent variability in sampling phenomena such as information exchange, and the use of proportional rather than raw data to allow for comparisons of narratives of varying lengths/different totals of content words, it was not possible to carry out statistical analyses to determine which of the changes noted were statistically significant. However, on the basis of the substantial gains in content words conveyed and the consistency of gains across simple and complex narratives, there appeared to be some evidence for direct and consistent effects of therapy driving some of these 
gains for two CPs. Specifically, Paula (gain in simple narrative: $27.18 \%$, complex: 18.4\%, mean difference: $23.02 \%$ ) and strongest overall for Peter (simple narrative: 9.23\%, complex $36.8 \%$, mean difference: $22.78 \%$ ).

The data from the other two CPs were less clear. Noel showed a note-worthy gain of $25.63 \%$ for the simple narrative, but this was reduced in the mean score of $10.37 \%$ by a complex narrative score of $-4.9 \%$. Eve was consistent across simple and complex with depleted scores for both $(-12.82 \% ;-6.21 \%$; mean: $-9.52 \%)$. Given that the therapy was unlikely to reduce information exchange between couples, this negative score suggests there may have been a lot of noise in these data and caution is required when interpreting positive therapy effects.

4.2 What specific behaviours drive the changes in the quantity of new information exchanged for one couple?

Further analysis was carried out for the $\mathrm{CP}$ who demonstrated the largest gain following therapy, i.e., Peter. From a broad perspective, Peter's output in pre- and post-therapy storytelling data was investigated regarding his overall contribution to the interactions (see Table 3); his contribution to co-constructing the story increased substantially following therapy, from a mean of 41 contributions pre-therapy (SD: $2.83)$ to 138.5 post-therapy (SD: 38.89 ).

Table 3 about here

\subsubsection{Broad categories}


Given the differences in the Peter's contributions before and after therapy, proportional data were used to compare behaviours across story type (simple and complex) and time (pre- and post-therapy). As demonstrated in Figure 2, decreases were observed in the Peter's display of a lack of understanding and 'other' behaviours (the latter including test questions, claiming understanding, passing turns and acknowledging Alicia's linguistic difficulties). Increases were observed in behaviours categorised as displaying understanding and referring to the story structure; proportional and raw data for the broad categories are shown in Table 4.

Figure 2 about here

Table 4 about here

\subsubsection{Specific behaviours}

Occurrence of specific behaviours used by Peter in the interactive storytelling data were analysed for changes in the frequency of use (see Figure 3). Following therapy, Peter displayed an increased role in co-constructing the story, as indicated by increased frequency of reformulations (mean 4.5\% increase), summaries (mean 5.2\% increase) and controlling the pace of Alicia's storytelling (mean 9.0\% increase). Decreases in the use of specific behaviours were observed for passing turns (mean $13.8 \%$ decrease), checking questions (mean $4.3 \%$ decrease) and claiming understanding (mean 4\% decrease).

Figure 3 about here 
These changes reflect behaviours targeted in therapy:

- increased use of summaries and controlling the pace of storytelling was facilitated through the 'Stop and check' goal (i.e., punctuating Alicia's storytelling by summaries what he had understood so far);

- increased use of summaries and reformulations was facilitated through the 'Move along' goal (i.e., during a lengthy and unproductive lexical search by Alicia, using summaries to reinforce help move the story along);

The behaviours observed to have undergone reductions in use (i.e., passing turns and claiming understanding) were not directly targeted in therapy; however, it may be argued that with Peter taking a more active role in constructing the story, he became less reliant on more passive behaviours such as claiming understanding and passing the floor back to Alicia.

Other behaviours that were targeted in treatment did not show change in analysis of the proportional data. For example, part of the goal 'Stop and check' included Peter contributing to the progression of the story by prompting Alicia with "What happened next?" questions. Analysis of the proportional data shows no change on this behaviour ( $7.5 \%$ pre-therapy and $7.4 \%$ post-therapy); however, numerically, the behaviour increased from a mean of 3 pre-therapy to a mean of 10.5 post-therapy. In general, Peter can be seen to greatly increase his participation in the storytelling after therapy; thus, it is possible that any change is obscured by the fact that the conversation partner's contributions are much greater post-therapy. 


\section{Discussion}

The current study aimed to extend previous work on transactional communication in storytelling (Ramsberger \& Menn, 2003; Ramsberger \& Rende, 2002) by investigating the effect of a novel intervention targeting transactional success within storytelling for people with non-fluent aphasia and their CPs. Drawing on the principles of thinking for speaking, the participants with aphasia were facilitated to segment video narrative into distinct events, to selectively highlight specific details of the story and to use a combination of verbal (e.g., syntactically reduced utterances, direct reported speech) and non-verbal resources (e.g., gesture, writing, drawing) in order to convey new information to their partner. Components of story grammar (e.g., setting the scene by introducing main characters) were used to facilitate narrative planning and production. For the CPs, therapy drew on the principles of conversation coaching to educate partners on their role within the interaction and ultimately increase facilitative behaviours within storytelling. It was hypothesised that the sum of these strands of therapy would be improved negotiation and construction of shared understanding within storytelling.

Effects of therapy were analysed by comparing simple and complex narrative data obtained at baseline and post-therapy. Transactional success was calculated on the CPs' retelling of the story. The simple and complex narratives used at baseline and post-therapy were broadly matched but crucially were different to each other and therefore novel narratives. Three CPs demonstrated numerical improvement in mean storytelling post-therapy ('Peter', 'Paula' and 'Noel'). Given the variability inherent in interactional phenomena, it was prudent to only take very substantial changes in information exchange, and to consider consistency of gains, as possibly reflecting a 
therapy effect. The CPs differed in relation to patterns of improvement across story complexity: for 'Peter', larger change was seen on the complex story, while for 'Paula' and 'Noel' the opposite was true with both performing better in retelling the simple story. The remaining partner ('Eve') was unique in demonstrating numerically slightly lower accuracy of story retell after therapy. A conservative conclusion was drawn that two of four CPs (Peter and Paula) presented with sufficient evidence to suggest likely direct effects of therapy in terms of more effective information exchange strategies deployed by the PWA, and more facilitative interactive strategies utilised by the CP. The combination of these two strands appeared to converge in the positive outcomes of the $\mathrm{CP}$ being able to convey novel information with greater levels of detail relative to comparable narratives obtained at baseline. Further related research would be aided by establishing more precise measures relating to narrative complexity through closer matching of related narratives (e.g. ensuring that simple narratives are matched for identical numbers of complications, key words, etc.) This could allow for use of non-parametric analyses of apparent differences between pre and post therapy narrative samples in order to more formally evaluate whether differences are statistically significant. That said, the tactic of evaluating CPs' retelling of a narrative to which they were blind, appeared to be a promising outcome measure which was both engaging and of interest to all of these participants, and represented a middle ground between experimentally controlled tasks for eliciting monologic aphasic data and the more ecological but unconstrained sampling of conversation data.

The current study represented an attempt to develop some degree of standardisation within an interactive therapy protocol. Given the tradition of interactive and 
conversation analysis therapy methods of having been highly data driven and individualised in terms of therapy focus, the method described here represents an attempt to develop a standardised template for intervention delivery and measurement. Storytelling plays a vital role in making sense of the world, particularly in the wake of a traumatic life experience (Kellas \& Trees, 2006). Evidence suggests PWA engage significantly less in storytelling than their healthy counterparts (Davidson et al., 2003); thus, storytelling presents a psychosocially and clinically valid context for therapeutic focus. The method evaluated within the current study has been characterised as a template consisting of a) working with the PWA to deliver new information in the context of storytelling, b) working with the CP to collaborate in the construction of the story. While the precise advice and recommended strategies for a particular couple are tailored and individualised, this will be within the limits of the central task of information exchange. This move towards some flexible standardisation may support clinical application of this method, given that it is a defined protocol which can be applied in a time efficient manner without preplanning. Similarly, use of first session information exchange measures can serve as baseline measures for subsequent post-therapy evaluation which has ease of use and real-world clinical plausibility.

While analysis within the current study focused on the $\mathrm{CP}$, this does not exclude the possibility that changes on outcome measures reflect changes in patterns of output by the PWA. It is plausible that such changes are driven (at least partially) by changes in the PWA's storytelling either at the level of communication (e.g., increased awareness of the burden on the CPs), macro-linguistics (e.g., segmentation of the story, selectivity regarding peripheral vs core details of the story, story grammar) or 
micro-linguistics (e.g., designing output for maximum communicative effect by focusing on semantic specificity and forgoing grammaticality). For the purpose of this study, analysis focused on the CPs' behaviours for a number of reasons. Firstly, although therapy targeted both the PWA and CP separately, it was hypothesised that the sum of these two strands would be greater than the individual parts, i.e., improved negotiation and construction of shared understanding within storytelling and increased awareness of the resources at both speakers' disposal to create sharing understanding. Secondly, within interaction, speakers' turns are inextricably linked (Beeke et al., 2011); thus, it may be inappropriate to attempt to distinguish ownership of specific changes with interaction. The methods used within this study represent a practical step towards quantifying aspects relating to the conversation partner's behaviours within storytelling. This does not, of course, preclude analysis of the PWA within storytelling in future work.

"The ultimate goal of aphasia rehabilitation is a social one: to optimize the communication between the person with aphasia and his or her environment" (van de Sandt-Koenderman et al., 2012). The range of aphasia therapies have been conceptualised as deficit-focused, functional/disability-focused or participant-focused (World Health Organisation: International Classification of Functioning, Disability and Health (ICF), 2001). This study represents an attempt to combine elements from impairment-focused therapy (i.e., thinking for speaking and story grammar) and a disability-focused therapy (i.e., conversation coaching targeting the partner) in order to target the exchange of new information within storytelling. The inclusion of the $\mathrm{CP}$ within therapy acknowledges the important roles played by both the PWA and the CP in constructing shared understanding. Employing therapy techniques from various 
approaches reflects clinical practice where therapists combine all approaches at their disposal in supporting a PWA and their family through aphasia rehabilitation. Therapy stimuli were sourced from YouTube and viewed using an iPad, thus utilising widely available technology to create interesting, age-appropriate materials. Whilst further research is required to expand this model of treatment delivery and outcome measurement to a larger group of participants, the current study offers a novel approach whereby an important aspect of everyday communication - conveying new information - is targeted through the production patterns of the PWA and shaping facilitative behaviours of the CP. Such intervention may have implications for establishing and maintaining relationships, a sense of achievement for the PWA and $\mathrm{CP}$, and, more broadly, quality of life. 


\section{References}

Armstrong, E. (2000). Aphasic discourse analysis: The story so far. Aphasiology , 14, 875892.

Bastiaanse, R., \& Jonkers, R. (1998). Verb retrieval in action naming and spontaneous speech in agrammatic and anomic aphasia. Aphasiology, 12, 951-969.

Bates, E., Andonova, E., D’Amico, S., Jacobsen, T., Kohnert, K., Lu, C., et al. (2000). Introducing the CRL International Picture-Naming Project (CRL-IPNP). La Holla: University of California San Diego. Centre for Research in Language Newsletter. Beeke, S., Maxim, J., Best, W., \& Cooper, F. (2011). Redesigning therapy for agrammatism: Initial findings from the ongoing evaluation of a conversation-based intervention study. Journal of Neurolinguistics , 24, 222-236.

Bierren, J., Kenyon, G., Ruth, J., Shroots, J., \& Svendson, J. (1996). Aging and biography: Explorations in adult development. New York: Springer.

Bradley, M., \& Douglas, J. (2008). Conversation partner training - its role in aphasia. Acquiring Knowledge in Speech, Language and Hearing, 10, 18-21.

Bronken, B., Kirkevold, M., Martinsen, R., \& Kvigne, K. (2012). The aphasic storyteller: Co-constructing stories to promote psychosocial well-being after stroke. Qualitative Health Research , 22, 1303-1316.

Carragher, M., Conroy, P., Sage, K., \& Wilkinson, R. (2012). Can impairmentfocused therapy change the everyday conversations of people with aphasia? A review of the literature and future directions. Aphasiology, 26, 895-916.

Carragher, M., Sage, K., \& Conroy, P. (2013). The effects of verb retrieval therapy for people with non-fluent aphasia: Evidence from assessment tasks and conversation. Neuropsychological Rehabilitation, 23 (6), 846-887. 
Davidson, B., Worrall, L., \& Hickson, L. (2003). Identifying the communication activities of older people with aphasia: Evidence from naturalistic observation. Aphasiology, 17, 243-264.

Davidson, B., Worrall, L., \& Hickson, L. (2003). Identifying the communication activities of older people with aphasia: Evidence from naturalistic observation. Aphasiology, 17, 243-264.

De Roo, E., Kolk, H., \& Hofstede, B. (2003). Structural properties of syntactically reduced speech: A comparison of normal speakers and Broca's aphasics. . Brain and Language , 86, 99-115.

Druks, J. (2002). Verbs and nouns—a review of the literature. Journal of Neurolinguistics , 15, 289-315.

Druks, J., \& Masterson, J. (2000). The Object Action Naming Battery. Hove, UK: Psychology Press.

Edmonds, L., Nadeau, S., \& Kiran, S. (2009). Effect of Verb Network Strengthening Treatment (VNeST) on lexical retrieval of content words in sentences in persons with aphasia. Aphasiology , 23, 402-424.

Faroqi-Shah, Y. (2008). A comparison of two theoretically driven treatments for verb inflection deficits in aphasia. Neuropsychologia , 46, 3088-3100.

Garrett, M. (1988). Processes in language production. In F. (. Newmeyer (Ed.), Linguistics: The Cambridge Survey: III Language: Psychological and Biological Aspects. Cambridge: Cambridge University Press.

Goodglass, H., Kaplan, E., \& Barresi, B. (2001). The Boston Diagnostic Aphasia Examination (BDAE). Baltimore, Lippincott.

Goodwin, C. (1995). Co-constructing meaning in conversations with an aphasic man. Research on Language and Social Interactions , 28, 233-260. 
Hengst, J., Frame, S., Neuman-Stritzel, T., \& Gannaway, R. (2005). Using others' words: conversational use of reported speech by individuals with aphasia and their communication partners. Journal of Speech, Language and Hearing Research, 48, 137-156.

Hernandez-Sacristan, C., \& Rosell-Clari, V. (2009). Syntax and conversation in aphasia. A strategic restrictive use of Spanish and Catalan connector QUE by aphasic speakers. Clinical Linguistics \& Phonetics , 23, 717-741.

Hopper, T., Holland, A., \& Rewega, M. (2002). Conversational coaching: Treatment outcomes and future directions. Aphasiology , 16, 745-761.

Jones, E. (1986). Building the foundations for sentence production in a non-fluent aphasic. British Journal of Disorders of Communication , 21, 63-82.

Kellas, J., \& Trees, A. (2006). Finding meaning in difficult family experiences: Sense-making and interaction processes during joint family storytelling. Journal of Family Communication , 6, 49-76.

Kolk, H. (1995). A time-based approach to agrammatic production. Brain and Language , 50, 282-303.

Labov, W. (1972). The transformation of experience in narrative syntax. In W. Labov, Language and the inner city. Philadelphia: University of Pennsylvania.

Lee, M., \& Thompson, C. (2004). Agrammatic aphasic production and comprehension of unaccusative verbs in sentence contexts. Journal of Neurolinguistics , 17, 315-330.

Marhsall, J., \& Cairns, D. (2005). Therapy for sentence processing problems in aphasia: Working on thinking for speaking. Aphasiology , 19, 1009-1020. Marshall, J. (2009). Framing ideas in aphasia: the need for thinking therapy. International Journal of Language \& Communication Disorders , 44, 1-14. 
Marshall, J. (2002). The assessment and treatment of sentence processing disorders: A review of the literature. In A. (. Hillis (Ed.), Handbook on adult language disorders: Integrating cognitive neuropsychology, neurology and rehabilitation. New York: Psychology Press.

Mayer, J., \& Murray, L. (2003). Functional measures of naming in aphasia: Word retrieval in confrontation naming versus connected speech. Aphasiology, 17, 481497.

McAdams, D. (2001). The psyhology of life stories. Review of General Psychology, $5,100-122$

McNeil, M., Robin, D., \& Schmidt, R. (2008). Apraxia of speech: Definition and differential diagnosis. In M. McNeil, Clinical Management of Sensorimotor Speech Disorders (2nd Edition ed.). New York: Thieme Medical Publishers.

McNeil, M., Robin, D., \& Schmidt, R. (2008). Apraxia of speech: Definition and differential diagnosis. In: . In M. McNeil (Ed.), Clinical Management of Sensorimotor Speech Disorders (2nd Edition ed.). New York: Thieme Medical Publishers. McRae, K., Hare, M., Elman, J., \& Ferretti, T. (2005). A basis for generating expectancies for verbs from nouns. Memory and Cognition, 33, 1174-1184. Mitchum, C., \& Berndt, R. (2001). Cognitive neuropsychological approaches to diagnosing and treating language disorders: Production and comprehension of sentences. In R. (. Chapey (Ed.), Language intervention strategies in aphasia and related neurogenic communication disorders. Baltimore, MD: Williams \& Wilkins. Mitchum, C., \& Berndt, R. (1992). Verb retrieval and sentence construction: Effects of targeted intervention. In G. Humphreys, \& J. (. Riddoch (Eds.), Cognitive neuropsychology and cognitive rehabilitation. Hove, UK: Lawrence Erlbaum Associates Ltd. 
Mitchum, C., Greenwald, M., \& Berndt, R. (2000). Cognitive treatments of sentence processing disorders: What have we learned? . Neuropsychological Rehabilitation, $10,311-336$

Mitchum, C., Haendiges, A., \& Berndt, R. (1993). Model-guided treatment to improve written sentence production: A case study. Aphasiology , 7, 71-109.

Morris, J., Franklin, S., Menger, F., \& GD. (2011). Returning to work with aphasia, A case study. Aphasiology, 25, 890-907.

Norrick, N. (2000). Conversational narrative: Storytelling in everyday talk. Amsterdam, Philadelphia: John Benjamins Pub.

Ramsberger, G., \& Menn, M. (2003). Co-Constructing Lucy: Adding a Social Perspective to the Assessment of Communicative Success in Aphasia. In G. Goodwin, Conversation and Brain Damage. New York: Oxford University Press.

Ramsberger, G., \& Rende, B. (2002). Measuring transactional success in the conversation of people with aphasia. Aphasiology, 16, 337-353.

Randall, W. (2001). Acquiring a narrative perspective on aging, identity and everyday life. In G. Kenyon, P. Clark, \& B. De Vries, Narrative gerontology: Theory, research and practice. New York: Springer.

Riessman, C. (1993). Narrative analysis. Thousand Oaks, CA: Sage.

Rochon, E., Laird, L., Bose, A., \& Scofield, J. (2005). Mapping therapy for sentence production impairments in nonfluent aphasia. Neuropsychological Rehabilitation , 15, $1-36$.

Rodriguez, A., Worrall, L., McKinnon, E., Grohn, B., Brown, K., Van Hees, S., et al. (2013). Therapeutic effect of an intensive, comprehensive aphasia program: Aphasia LIFT. Clinical Aphasiology Conference. Tucson, AZ: Clinical Aphasiology Conference. 
Ruiter, M., Kolk, H., \& Rietveld, T. (2010). Speaking in ellipses: The effect of a compensatory style of speech on functional communication in chronic agrammatism. Neuropsychological Rehabilitation, 20, 423-458.

Rumelhart, D. (1975). Notes on a schema for stories. In D. Bobrow, \& A. Collins, Representation and Understanding: Studies in Cognitive Science. New York, NY: Academic Press.

Saffran, E., Schwartz, M., \& Marin, O. (1980). The word order problem in agrammatism: Production. Brain and Language , 10, 263-280.

Schlenck, K., Schlenck, C., \& Springer, L. (1995). Die Behandlung des schweren Agrammatismus - Reduzierte-Syntax-Therapie (REST). Thieme: Stuttgart.

Schwartz, M., Saffran, E., Fink, R., Myers, J., \& Martin, N. (1994). Mapping therapy: A treatment programme for agrammatism. Aphasiology, 8, 19-54.

Simmons-Mackie, N., Kearns, K., \& Potechin, G. (2005). Treatment of aphasia through family member training. Aphasiology, 19, 583-593.

Springer, L., Huber, W., Schlenck, K., \& Schlenck, C. (2000). Agrammatism: Deficit or compensation? Consequences for aphasia therapy. Neuropsychological Rehabilitation , 10, 279-309.

Thompson, C., Shapiro, L., Li, L., \& Schendel, L. (1995). Analysis of verbs and verbargument structure. A method for quantification of aphasic language production.

Clinical Aphasiology, 23, 121-140.

Turner, S., \& Whitworth, A. (2006). Conversational partner training programmes in aphasia: A review of key themes and participants' roles. Aphasiology , 20, 483-510. Van De Sandt-Koenderman, M., Van Der Meulen, I., \& Ribbers, G. (2012). Aphasia Rehabiltiation, More than treating the language disorder. Archives of Physical Medicine and Rehabilitation, 93, S1-3. 
Van De Sandt-Koenderman, W., Bonta, E., Wielaert, S., \& Visch-Brink, E. (1997).

Stimulating sentence production in agrammatic patients: The effect of the Visual Cue Programme on spontaneous speech. Aphasiology, 11, 735-759.

Webster, J., \& Gordon, B. (2008). Contrasting therapy effects for verb and sentence processing difficulties: A discussion of what worked and why. Aphasiology, 23, $1231-1251$.

Webster, J., Morris, J., \& Franklin, S. (2005). Effects of therapy targeted at verb retrieval and the realisation of the predicate argument structure: A case study. Aphasiology, 19, 748-764.

Weinrich, M., McCall, D., Boser, K. I., \& Virata, T. (2002). Narrative and Procedural Discourse Production by Severely Aphasic Patients. Neurorehabilitation and Neural Repair , 16, 249-274.

Whitworth, A. (2010). Using narrative as a bridge: Linking language processing models with real-life communciation. Seminars in speech and language, 31, 64-75. Wilkinson, R., Bryan, K., Lock, S., \& Sage, K. (2010). Implementing and evaluating aphasia therapy targeted at couples' conversations: A single case study. Aphasiology, $24,869-886$.

(2001). World Health Organisation: International Classification of Functioning, Disability and Health (ICF). 


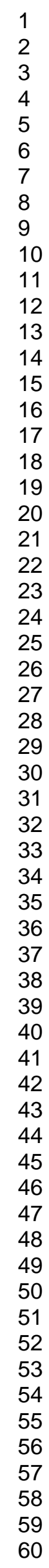


Appendix 1: Example of video stimuli used during therapy

Geri's game (Pixar short film) is a 3:50 minute video clip http://www.youtube.com/watch?v=9IYRC7g2ICg

Summary: It's autumn and an elderly man is in the park alone setting up a game of chess. He proceeds to play with his own aliais as an opponent. As he moves to each side of the chessboard, he plays as a different 'character' - on one side of the board he wears his glasses and is a timid character; on the other side of the board he takes off his glasses and is a competitive and somewhat aggressive character. As the game progresses, the competitive character (without the glasses) is winning. The timid character (with glasses) pretends to have a heart attack and, while his "opponent" is distracted, switches the chessboard so that he is winning. Once the game resumes, the competitive character realises he is no longer winning the game and he resigns. As the prize, he hands over a set of false teeth. As the camera pans over from the park, the man is seen sitting alone at the chessboard. 
Appendix 2: Individual goals for PWA and their conversation partners

\begin{tabular}{|c|c|c|c|}
\hline Initials & PWA & $\mathbf{C P}$ & Goals for therapy \\
\hline $\mathrm{BL}$ & $\square$ & & $\begin{array}{l}\text { Set the scene: detail the initial contextual information } \\
\text { about the story or give a general impression of the tone of } \\
\text { the story } \\
\text { Chunk it up: think about the story in smaller, more } \\
\text { manageable chunks } \\
\text { Drip drip: tell the story bit by bit, leaving time for partner } \\
\text { to ask questions } \\
\text { Show and tell: use gesture or acting in combination with } \\
\text { speech to convey parts of the story }\end{array}$ \\
\hline Paula & & $\square$ & $\begin{array}{l}\text { Stop and check: check your understanding as you go along } \\
\text { by asking questions and summarising what you've } \\
\text { understood } \\
\text { Who does what: establish how many people are involved } \\
\text { in the story and their role within the story } \\
\text { Pinpoint: be specific about what you understand and what } \\
\text { you don't understand }\end{array}$ \\
\hline $\mathrm{JH}$ & $\square$ & & $\begin{array}{l}\text { Stop and listen: use conversation partner's questions to } \\
\text { clarify details of the story with yes/no responses } \\
\text { Set the scene: detail the initial contextual information } \\
\text { about the story or give a general impression of the tone of } \\
\text { the story } \\
\text { Chunk it up: think about the story in smaller, more }\end{array}$ \\
\hline
\end{tabular}




\begin{tabular}{|l|l|l|}
\hline $\mid$ & $\begin{array}{l}\text { about the story or give a general impression of the tone of } \\
\text { the story } \\
\text { Drip drip: tell the story bit by bit, leaving time for partner } \\
\text { to ask questions } \\
\text { Show and tell: use gesture or acting in combination with } \\
\text { speech to convey parts of the story } \\
\text { Eve }\end{array}$ & $\begin{array}{l}\text { Move on: if you know the word the PWA is trying to say, } \\
\text { keep the conversation going. If you don't know the word, } \\
\text { ask questions such as "Do you mean....?" } \\
\text { Who does what: establish how many people are involved } \\
\text { in the story and their role within the story } \\
\text { Pinpoint: be specific about what you understand and what } \\
\text { you don't understand }\end{array}$ \\
\hline
\end{tabular}


Appendix 3: CPs' retelling of stories, scored in comparison to the most frequently occurring content words produced by control participants

\begin{tabular}{|c|c|c|c|c|}
\hline $\begin{array}{l}\text { Pre-therapy simple } \\
\text { narrative target }\end{array}$ & Peter & Eve & Paula & Noel \\
\hline $\begin{array}{l}\text { Mr Bean drives into a car } \\
\text { park in a mini } \\
\text { Mr Bean (1) } \\
\text { drives (1) } \\
\text { car park/parking lot (1) } \\
\text { mini (1) }\end{array}$ & $\begin{array}{l}\text { Well Mr Bean (1)... with } \\
\text { Rowan Atkinson in it was } \\
\text { a TV programme... and I } \\
\text { assuming that this... this } \\
\text { part of a TV programme... } \\
\text { which shows Atkinson as } \\
\text { Mr Bean... driving (1) into } \\
\text { a car park (1) with his } \\
\text { usual incompetence... }\end{array}$ & $\begin{array}{l}\text { He saw a car (1) going into } \\
\text { a car park (1)... the bloke } \\
\text { who turned out to be } \\
\text { Rowan Atkinson (1) }\end{array}$ & $\begin{array}{l}\text { Rowan Atkinson (1) } \\
\text { driving (1) a car (1)... }\end{array}$ & $\begin{array}{l}\text { Right I think Ron } \\
\text { Atkinson was driving (1) a } \\
\text { mini (1) into a car park } \\
\text { (1)... }\end{array}$ \\
\hline
\end{tabular}




\begin{tabular}{|c|c|c|c|c|}
\hline $\begin{array}{l}\text { ticket machine (1) } \\
\text { can't reach (1) } \\
\text { ticket (1) }\end{array}$ & & & & \\
\hline $\begin{array}{l}\text { He uses a grabber to get } \\
\text { the ticket } \\
\text { grabber/stick/litter picker } \\
\text { (1) } \\
\text { get/grab/pull out (1) } \\
\text { ticket (1) }\end{array}$ & $\begin{array}{l}\text { so he has some sort of } \\
\text { extended arm (1)... and } \\
\text { then gets (1) the ticket } \\
\text { (1)... out of the machine... }\end{array}$ & $\begin{array}{l}\text { so he got something I } \\
\text { presume out of the car... } \\
\text { like a grabber thing a pick- } \\
\text { me-up thing (1) to pull out } \\
\text { (1) the ticket (1) }\end{array}$ & $\begin{array}{l}\text { and he used his stick (1) to } \\
\text { either push the plastic card } \\
\text { in or... type out something } \\
\text { or other I don't know I } \\
\text { don't really know }\end{array}$ & $\begin{array}{l}\text { so then he went inside the } \\
\text { car and he found a litter- } \\
\text { picking stick (1), reached } \\
\text { out of the car to press the } \\
\text { ticket, got (1) his ticket (1) }\end{array}$ \\
\hline $\begin{array}{l}\text { He drives recklessly into } \\
\text { the car park } \\
\text { drives (1) } \\
\text { recklessly/quickly (1) } \\
\text { car park (1) }\end{array}$ & $\begin{array}{l}\text { and drives off (1) I don't } \\
\text { know whether he's coming } \\
\text { in or going out... }\end{array}$ & $\begin{array}{l}\text { and then he went to park } \\
\text { (1) the car somewhere... } \\
\text { and it's was a black and... } \\
\text { yellow and black car }\end{array}$ & & $\begin{array}{l}\text { and then drove (1) ... into } \\
\text { the car park (1) and then it } \\
\text { ended... and the car was } \\
\text { either yellow or cream }\end{array}$ \\
\hline Total: 15 & 9 & 10 & 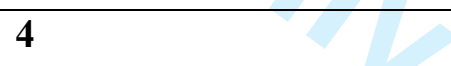 & 10 \\
\hline
\end{tabular}




\begin{tabular}{|c|c|c|c|c|}
\hline $\begin{array}{l}\text { Post-therapy simple } \\
\text { narrative target }\end{array}$ & Peter & Eve & Paula & Noel \\
\hline $\begin{array}{l}\text { Mr Bean is in the pool, } \\
\text { looking around } \\
\text { Mr Bean/he (1) } \\
\text { arrives (1) } \\
\text { pool (1) } \\
\text { looking/had a look around } \\
\text { (1) }\end{array}$ & $\begin{array}{l}\text { Mr Bean (1) eh Mr } \\
\text { Bean... the scene appears } \\
\text { to be Mr Bean walks into a } \\
\text { swimming pool (1) }\end{array}$ & $\begin{array}{l}\text { Right so back to the } \\
\text { swimming pool (1)... Mr } \\
\text { Bean (1) again... so I } \\
\text { assume from that it was } \\
\text { going to be funny... he's } \\
\text { standing on the side of the } \\
\text { pool wearing his trunks... }\end{array}$ & $\begin{array}{l}\text { Right what I got... Rowan } \\
\text { Atkinson (1)... and he said } \\
\text { slide at first... well he said } \\
\text { there were two slides at } \\
\text { first didn't he... but I- I } \\
\text { never carried on with two } \\
\text { slides... and then I found } \\
\text { out it were in swimming } \\
\text { baths and the slides were } \\
\text { in the swimming baths (1) }\end{array}$ & $\begin{array}{l}\text { Right... Mr Bean (1) again } \\
\text { he's still in the swimming } \\
\text { pool (1) but he's sort of on } \\
\text { the side... looking round } \\
\text { (1) at the excitement }\end{array}$ \\
\hline
\end{tabular}




\begin{tabular}{|c|c|c|c|c|}
\hline $\begin{array}{l}\text { go on it/have a go/drawn } \\
\text { to (1) }\end{array}$ & & & & \\
\hline $\begin{array}{l}\text { As he's about to slide into } \\
\text { the water, the lifeguard } \\
\text { blows the whistle } \\
\text { sat on/got on/go on/have a } \\
\text { play/slide down (1) } \\
\text { lifeguard (1) } \\
\text { blows } \\
\text { whistle/whistles/stop/get } \\
\text { off (1) }\end{array}$ & $\begin{array}{l}\text { so in his clumsy way he } \\
\text { clambers (1) onto the slide } \\
\text { and then.... where they're } \\
\text { all possibly jumbled } \\
\text { together he's about to join } \\
\text { into this and the attendant } \\
\text { (1) comes along and says } \\
\text { "oi we're not having this } \\
\text { (1)... you're... it's } \\
\text { dangerous or whatever it } \\
\text { is" }\end{array}$ & $\begin{array}{l}\text { started going up (1) but he } \\
\text { got stopped (1) by the } \\
\text { instructor (1) who said he } \\
\text { couldn't... and for } \\
\text { children only... }\end{array}$ & $\begin{array}{l}\text { anyway... it sounded like } \\
\text { he were coming down (1) } \\
\text { and he shouldn't have } \\
\text { been... he were doing } \\
\text { something wrong... and } \\
\text { lifeguard (1) or something } \\
\text { like life guard whatever... } \\
\text { at swimming baths... were } \\
\text { complaining to him... } \\
\text { telling him he hadn't to do } \\
\text { it (1) no no no... }\end{array}$ & $\begin{array}{l}\text { so he goes over there and } \\
\text { he's like going up (1) the } \\
\text { steps and then he gets to } \\
\text { the top sort of thing... and } \\
\text { the life guard (1) whistles } \\
\text { (1) and says you're not } \\
\text { allowed on there (1) it's } \\
\text { only for... young children } \\
\text { or whatever... }\end{array}$ \\
\hline
\end{tabular}




\begin{tabular}{|l|l|l|l|l|}
\hline & & & & $\begin{array}{l}\text { down (1)... while the life } \\
\text { guard watching and } \\
\text { doesn't go on the slide }\end{array}$ \\
\hline Total: 13 & & & & $\mathbf{7}$ \\
\hline
\end{tabular}

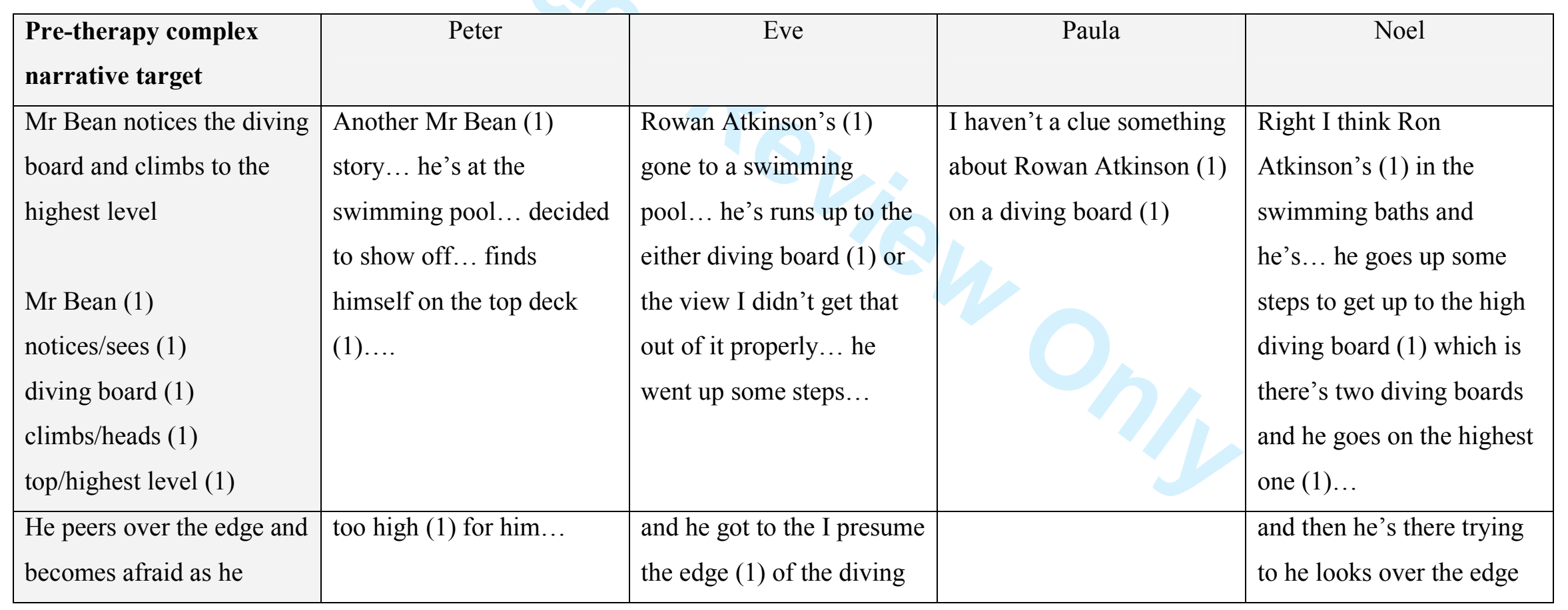




\begin{tabular}{|c|c|c|c|c|}
\hline $\begin{array}{l}\text { realises the height and } \\
\text { holds on to the rail } \\
\text { peers over/looks down (1) } \\
\text { edge (1) } \\
\text { afraid/panicked/frightened } \\
\text { (1) } \\
\text { holds on (1) } \\
\text { rail (1) }\end{array}$ & & $\begin{array}{l}\text { board... didn't like it (1), } \\
\text { flapped his arms... then he } \\
\text { turned round as if he was } \\
\text { going to perhaps dive } \\
\text { backwards... }\end{array}$ & & $\begin{array}{l}\text { (1) and he's too scared (1) } \\
\text { so he yelps out and jumps } \\
\text { back... and sort of holds } \\
\text { onto (1) the handle rail (1) } \\
\text { he's quivering and he's all } \\
\text { scared... }\end{array}$ \\
\hline $\begin{array}{l}\text { Two boys appear on the } \\
\text { diving board } \\
\text { two (1) } \\
\text { boys (1) } \\
\text { appear/come up (1) }\end{array}$ & $\begin{array}{l}\text { and I imagine the lads (1) } \\
\text { are showing off and.... } \\
\text { Winding him up and } \\
\text { diving off the board I'm } \\
\text { not quite sure if they were } \\
\text { spring board or at the top }\end{array}$ & $\begin{array}{l}\text { and then two (1) lads (1) } \\
\text { two children appeared } \\
\text { (1)... not quite sure where } \\
\text { they came from... }\end{array}$ & $\begin{array}{l}\text { and he had mates... that's } \\
\text { it I don't know what he } \\
\text { were doing with his hand } \\
\text { up there like that ((mimics } \\
\text { BL's raised hand)) }\end{array}$ & $\begin{array}{l}\text { and then there's two (1) } \\
\text { lads (1) who come up } \\
\text { (1)... oh and he's wearing } \\
\text { trunks that have got blue } \\
\text { and orange and maybe } \\
\text { some other colours on... } \\
\text { but then he... }\end{array}$ \\
\hline $\begin{array}{l}\text { The boys look impatient so } \\
\text { Mr Bean pretends not to } \\
\text { be afraid and has to dive in }\end{array}$ & & & $\begin{array}{l}\text { he were he said he were } \\
\text { frightened or nervous or... }\end{array}$ & $\begin{array}{l}\text { because he's so scared } \\
\text { they're sort of... sort of... } \\
\text { taking the mick out of him }\end{array}$ \\
\hline
\end{tabular}




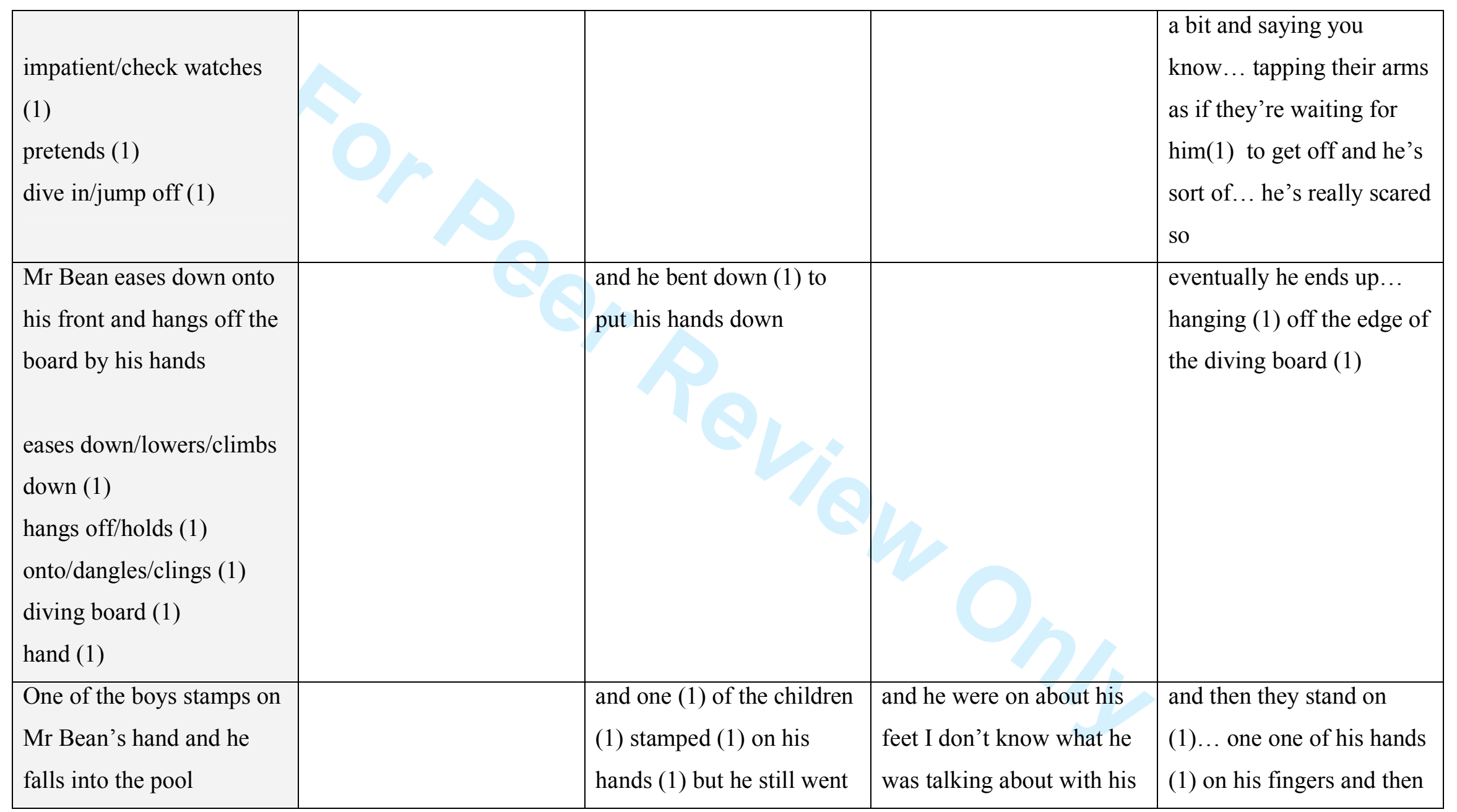




\begin{tabular}{|c|c|c|c|c|}
\hline $\begin{array}{l}\text { one (1) } \\
\text { boys/lads (1) } \\
\text { stamps (1) } \\
\text { hand/finger (1) } \\
\text { falls (1) } \\
\text { pool (1) }\end{array}$ & 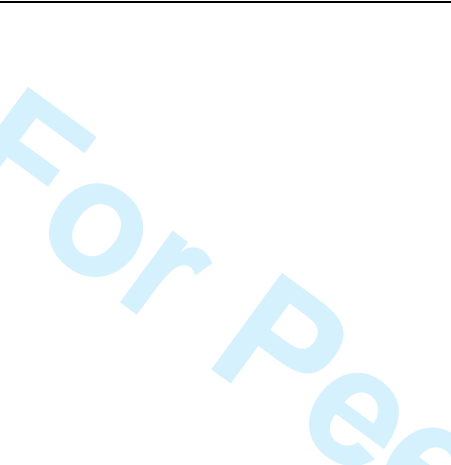 & $\begin{array}{l}\text { in the water (1) in a } \\
\text { fashion... }\end{array}$ & $\begin{array}{l}\text { feet... can't think of owt } \\
\text { else... he didn't tell me } \\
\text { much did he }\end{array}$ & $\begin{array}{l}\text { he drops (1) into the water } \\
\text { (1) and... sort of dives }\end{array}$ \\
\hline Total: 27 & 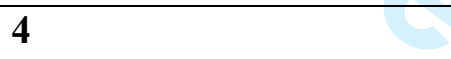 & 13 & 2 & 17 \\
\hline
\end{tabular}

\begin{tabular}{|c|c|c|c|c|}
\hline $\begin{array}{l}\text { Post-therapy complex } \\
\text { narrative target }\end{array}$ & Peter & Eve & Paula & Noel \\
\hline $\begin{array}{l}\text { Mr Bean is in the pool and } \\
\text { realises his trunks have } \\
\text { come off and are floating } \\
\text { in the water } \\
\text { Mr Bean (1) } \\
\text { realises/notices (1) }\end{array}$ & $\begin{array}{l}\text { Mr Bean's (1) in the } \\
\text { pool... swimming or } \\
\text { trying to swim in his usual } \\
\text { probably incompetent } \\
\text { way... til he discovers a } \\
\text { pair of trunks (1) floating } \\
\text { (1) about... and he thought }\end{array}$ & $\begin{array}{l}\text { Back at the pool again... } \\
\text { Mr Bean's (1) in the } \\
\text { water... without any } \\
\text { trunks (1) on... they've } \\
\text { fallen off (1) ... not quite } \\
\text { sure why they would } \\
\text { have... but he wouldn't }\end{array}$ & $\begin{array}{l}\text { Well Rowan Atkinson (1) } \\
\text { jumped in pool, lost (1) his } \\
\text { trunks (1)... }\end{array}$ & $\begin{array}{l}\text { It was Mr Bean (1) or } \\
\text { Rowan Atkinson... not } \\
\text { Ron Atkinson... and he } \\
\text { was... it was like a like a } \\
\text { follow-on of the diving } \\
\text { into the pool one which we } \\
\text { did ages ago... so he's in }\end{array}$ \\
\hline
\end{tabular}




\begin{tabular}{|c|c|c|c|c|}
\hline $\begin{array}{l}\text { trunks (1) } \\
\text { come off/lost (1) } \\
\text { floating (1) }\end{array}$ & $\begin{array}{l}\text { well I'm struggling now } \\
\text { cos I'm in the altogether... } \\
\text { (1) }\end{array}$ & $\begin{array}{l}\text { have probably know } \\
\text { that... }\end{array}$ & & $\begin{array}{l}\text { the pool and his trunk- and } \\
\text { he realises (1) he's } \\
\text { swimming about and he } \\
\text { realises that he hasn't got } \\
\text { his trunks (1) on and } \\
\text { they're on the side... }\end{array}$ \\
\hline $\begin{array}{l}\text { The lifeguard blows the } \\
\text { whistle to tell everyone to } \\
\text { get out of the pool so Mr }\end{array}$ & $\begin{array}{l}\text { by this time... for some } \\
\text { reason and I should have } \\
\text { asked because that's my }\end{array}$ & $\begin{array}{l}\text { the instructor (1) and an } \\
\text { assistant were on the pool } \\
\text { side... the pool- they got }\end{array}$ & & $\begin{array}{l}\text { but he just stays in the } \\
\text { water and then but then } \\
\text { it's the end of the... day so }\end{array}$ \\
\hline
\end{tabular}




\begin{tabular}{|c|c|c|c|}
\hline $\begin{array}{l}\text { Bean hides underwater } \\
\text { lifeguard (1) } \\
\text { blows whistle (1) } \\
\text { everybody out/get out (1) } \\
\text { pool (1) } \\
\text { hides/ducks down (1) } \\
\text { underwater (1) }\end{array}$ & $\begin{array}{l}\text { fault the pool cleared... } \\
\text { and Mr Bean was left in } \\
\text { there... whether it's } \\
\text { closing time or whatever } \\
\text { I'm not sure... and the } \\
\text { only people there are two } \\
\text { pool attendants (1)... so } \\
\text { he's... and one of them is } \\
\text { a female.... so Mr Bean is } \\
\text { struggling to... keep out of } \\
\text { sight if you will... he's } \\
\text { swimming about in the } \\
\text { altogether because he... } \\
\text { keeping under the water } \\
\text { (1) presumably to keep out } \\
\text { of sight (1) but having to } \\
\text { surface keeps surfacing... }\end{array}$ & $\begin{array}{l}\text { more people in and they } \\
\text { called time (1) it must } \\
\text { have been time to go... or } \\
\text { whatever to get out... so } \\
\text { they get called out... Mr } \\
\text { Bean didn't want to get } \\
\text { out he was embarrassed } \\
\text { cos he hadn't got his } \\
\text { trunks on... he looked } \\
\text { very sheepish... }\end{array}$ & $\begin{array}{l}\text { the whistle gets blown (1) } \\
\text { to... get out of the pool } \\
\text { (1)... so... he doesn't, he } \\
\text { tries to hide (1) under the } \\
\text { water (1) about three times } \\
\text { and they keep blowing the } \\
\text { whistle (1) and nobody } \\
\text { knows he's hid }\end{array}$ \\
\hline $\begin{array}{l}\text { When everyone has left } \\
\text { the pool, Mr Bean tries to }\end{array}$ & $\begin{array}{l}\text { and for some reason I } \\
\text { should have asked again }\end{array}$ & $\begin{array}{l}\text { eventually everybody had } \\
\text { got out of the pool... he }\end{array}$ & $\begin{array}{l}\text { and then everyone seems } \\
\text { to have gone away so he }\end{array}$ \\
\hline
\end{tabular}




\begin{tabular}{|c|c|c|c|}
\hline $\begin{array}{l}\text { sneak out of the pool } \\
\text { tries (1) } \\
\text { sneak out (1) } \\
\text { pool (1) }\end{array}$ & $\begin{array}{l}\text { the two pool attendants } \\
\text { left... but one of them so } \\
\text { he tries (1) to get out (1) }\end{array}$ & got out (1)... & $\begin{array}{l}\text { sort of... comes out (1) of } \\
\text { the pool and then tries (1) } \\
\text { to make his way to the } \\
\text { changing rooms }\end{array}$ \\
\hline $\begin{array}{l}\text { He hides from the female } \\
\text { lifeguard who has come } \\
\text { back into the pool } \\
\text { hides (1) } \\
\text { female (1) } \\
\text { lifeguard (1) } \\
\text { comes back (1) } \\
\text { pool (1) }\end{array}$ & $\begin{array}{l}\text { and one of them's a } \\
\text { woman (1)... so... that's } \\
\text { my fault I should have } \\
\text { asked for more detail } \\
\text { shouldn't I... the I can't... } \\
\text { I cannot rem- Mr Bean } \\
\text { then... gets out of the } \\
\text { pool... thinking he's safe } \\
\text { but by this time... well } \\
\text { he'll have got out of the } \\
\text { pool won't he but then the } \\
\text { woman that's right the } \\
\text { woman would see him and } \\
\text { he he starts running around }\end{array}$ & $\begin{array}{l}\text { the instructor walked away } \\
\text { but the assistant (1) was } \\
\text { still around... but hadn't } \\
\text { noticed that he hadn't got } \\
\text { any trunks on... }\end{array}$ & \\
\hline
\end{tabular}




\begin{tabular}{|c|c|c|c|c|}
\hline & trying to escape her... & & & \\
\hline $\begin{array}{l}\text { A group of girls come out } \\
\text { of the changing room, see } \\
\text { Mr Bean and scream so he } \\
\text { runs off } \\
\text { group (1) } \\
\text { girls/schoolgirls (1) } \\
\text { come out/come in (1) } \\
\text { see (1) } \\
\text { scream (1) } \\
\text { runs off/runs away (1) }\end{array}$ & $\begin{array}{l}\text { and by this time there are } \\
\text { more kids (1) have } \\
\text { appeared (1) into the pool } \\
\text { area so he then he dives } \\
\text { back in again so he's back } \\
\text { in the same position he } \\
\text { was in before... and that } \\
\text { appears to be the story } \\
\text { [great, anything else?]... } \\
\text { well I can't remember I } \\
\text { think it's cos I didn't ask } \\
\text { properly what actually } \\
\text { happened between Mr } \\
\text { Bean, the girl picking Mr } \\
\text { Bean's trunks up and... } \\
\text { these two attendants } \\
\text { appearing and } \\
\text { disappearing... whether }\end{array}$ & $\begin{array}{l}\text { Mr Bean walked towards } \\
\text { the changing room as } \\
\text { some girls- young girls (1) } \\
\text { came out (1)... and he got } \\
\text { all embarrassed and they } \\
\text { laughed a bit... and that } \\
\text { was the end of it }\end{array}$ & $\begin{array}{l}\text { and then... then Atkinson } \\
\text { got out naked... and he } \\
\text { were in front of all people } \\
\text { (1) that were watching or } \\
\text { on side of baths... and } \\
\text { they were in costumes they } \\
\text { were all people... waiting } \\
\text { to go into baths or been in } \\
\text { baths... and that's it } \\
\text { [asked to explain BL's } \\
\text { drawing] well that was } \\
\text { Rowan Atkinson but he } \\
\text { scrubbed him out... and } \\
\text { that was little boy on side } \\
\text { and they were trunks } \\
\text { there... little boy got his } \\
\text { trunks out of baths run off } \\
\text { and then he went up }\end{array}$ & $\begin{array}{l}\text { but then there's a big } \\
\text { group (1) of school girls } \\
\text { (1) outside who see (1) } \\
\text { him... naked and start } \\
\text { screaming (1) and he's } \\
\text { about a bit ((gestures } \\
\text { startled)) and then that's it }\end{array}$ \\
\hline
\end{tabular}




\begin{tabular}{|c|c|c|c|c|}
\hline & $\begin{array}{l}\text { Mr Bean was out of the } \\
\text { pool by that stage... and } \\
\text { when the kids arrive it's } \\
\text { all a bit of a bit of a sort of } \\
\text { intermix if you will }\end{array}$ & & $\begin{array}{l}\text { here... this is supposed to } \\
\text { be Rowan Atkinson and I } \\
\text { presume this is audience } \\
\text { and they were all in } \\
\text { swimming gear... so I } \\
\text { presume they were waiting } \\
\text { to go in or they had just } \\
\text { got out or something [and } \\
\text { what happened at the } \\
\text { end?] I don't know }\end{array}$ & \\
\hline Total: 31 & 16 & 13 & 8 & 18 \\
\hline
\end{tabular}


Table 1: Background information on the participants with aphasia

\begin{tabular}{ccccccc}
\hline Participants & Gender & Age of & Hand- & Occupation & Age at & TPO \\
& & leaving & edness & & time of & (months) \\
& & & & & stroke \\
& & & & & \\
\hline BL & Male & 16 & Right & Pub manager & 60 & 80 \\
JH & Female & 23 & Right & Teacher & 36 & 26 \\
PM & Female & 16 & Right & Secretary & 62 & 30 \\
\hline
\end{tabular}

TPO: time-post onset

URL: http://mc.manuscriptcentral.com/paph Email: c.f.s.code@exeter.ac.uk 
Table 2: Comparison of percentage salient content words reported by the CPs in preand post-therapy storytelling

\begin{tabular}{c|ccc|ccc|c}
\hline \multirow{2}{*}{ CP } & \multicolumn{3}{|c|}{ Simple narratives } & \multicolumn{3}{c|}{ Complex narratives } & Mean difference \\
& Pre- & Post- & & Pre- & Post- & & between pre- and \\
& therapy & therapy & Difference & therapy & therapy & Difference & post-therapy \\
\hline Paula & $26.67 \%$ & $53.85 \%$ & $27.18 \%$ & $7.41 \%$ & $25.81 \%$ & $18.4 \%$ & $22.78 \%$ \\
Noel & $66.67 \%$ & $92.3 \%$ & $25.63 \%$ & $62.96 \%$ & $58.06 \%$ & $-4.9 \%$ & $10.37 \%$ \\
Peter & $60.00 \%$ & $69.23 \%$ & $9.23 \%$ & $14.81 \%$ & $51.61 \%$ & $36.8 \%$ & $23.02 \%$ \\
Eve & $66.67 \%$ & $53.85 \%$ & $-12.82 \%$ & $48.15 \%$ & $41.94 \%$ & $-6.21 \%$ & $-9.52 \%$ \\
\hline
\end{tabular}


Table 3: Peter's contribution to storytelling pre- and post-therapy (raw data)

\begin{tabular}{l|cc}
\hline & Pre-therapy & Post-therapy \\
\hline Simple story & 43 & 111 \\
Complex story & 39 & 166 \\
Mean & $\mathbf{4 1}$ (SD 2.83) & $\mathbf{1 3 8 . 5}$ (SD 38.89) \\
\hline
\end{tabular}

16

17

18

19

20

21

22

23

24

25

26

27

28

29

30

31

32

33

34

35

36

37

38

39

40

41

42

43

44

45

46

47

48

49

50

51

52

53

54

55

56

57

58

59

60

URL: http://mc.manuscriptcentral.com/paph Email: c.f.s.code@exeter.ac.uk 
Table 4: Analysis of Peter's interactional behaviours across four broad categories pre- and post-therapy (proportional data depicted in brackets beside the raw data)

\begin{tabular}{|c|c|c|c|c|c|c|c|c|}
\hline \multirow{3}{*}{$\begin{array}{l}\text { Time: } \\
\text { Behaviour: } \\
\text { Lack of understanding }\end{array}$} & \multicolumn{4}{|c|}{ Pre-therapy } & \multicolumn{4}{|c|}{ Post-therapy } \\
\hline & $\begin{array}{l}\text { Simple } \\
\text { story }\end{array}$ & $\begin{array}{c}\text { Complex } \\
\text { story }\end{array}$ & Total & Mean & $\begin{array}{l}\text { Simple } \\
\text { story }\end{array}$ & $\begin{array}{c}\text { Complex } \\
\text { story }\end{array}$ & Total & Mean \\
\hline & $12(27.9 \%)$ & $12(30.8 \%)$ & $\begin{array}{l}24 \\
(58.7 \%)\end{array}$ & $\begin{array}{l}12(29.3 \%) \\
\text { St dev: } 0(2 \%)\end{array}$ & $\begin{array}{l}30 \\
(27.1 \%)\end{array}$ & $\begin{array}{l}38 \\
(22.8 \%)\end{array}$ & $68(49.9 \%)$ & $\begin{array}{l}34(25 \%) \\
\text { St dev: } 5.7(2.9 \%)\end{array}$ \\
\hline Display of understanding & $9(20.9 \%)$ & $8(20.5 \%)$ & $\begin{array}{l}17 \\
(41.4 \%)\end{array}$ & $\begin{array}{l}8.5(20.7 \%) \\
\text { St dev: } 0.7 \\
(0.3 \%)\end{array}$ & $\begin{array}{l}37 \\
(33.3 \%)\end{array}$ & $68(41 \%)$ & $105(74.3 \%)$ & $\begin{array}{l}52.5(37.1 \%) \\
\text { St dev: } 21.9 \\
(5.4 \%)\end{array}$ \\
\hline $\begin{array}{l}\text { Reference to story } \\
\text { structure }\end{array}$ & $2(4.7 \%)$ & $4(10.3 \%)$ & $6(14.9 \%)$ & $\begin{array}{l}3(7.5 \%) \\
\text { St dev: } 1.4(4 \%)\end{array}$ & $\begin{array}{l}19 \\
(17.1 \%)\end{array}$ & $\begin{array}{l}26 \\
(15.7 \%)\end{array}$ & $45(32.8 \%)$ & $\begin{array}{l}22.5(16.4 \%) \\
\text { St dev: } 4.9(1 \%)\end{array}$ \\
\hline Other & $20(46.5 \%)$ & $15(38.4 \%)$ & $35(85 \%)$ & $\begin{array}{l}17.5(42.5 \%) \\
\text { St dev: } 3.5 \\
(5.7 \%)\end{array}$ & $\begin{array}{l}25 \\
(22.5 \%)\end{array}$ & $\begin{array}{l}34 \\
(20.5 \%)\end{array}$ & $59(43 \%)$ & $\begin{array}{l}29.5(21.5 \%) \\
\text { St dev: } 6.4(1.4 \%)\end{array}$ \\
\hline
\end{tabular}




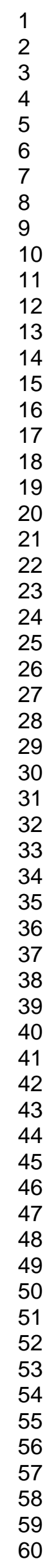


Figure 1: Overview of therapy sessions

4
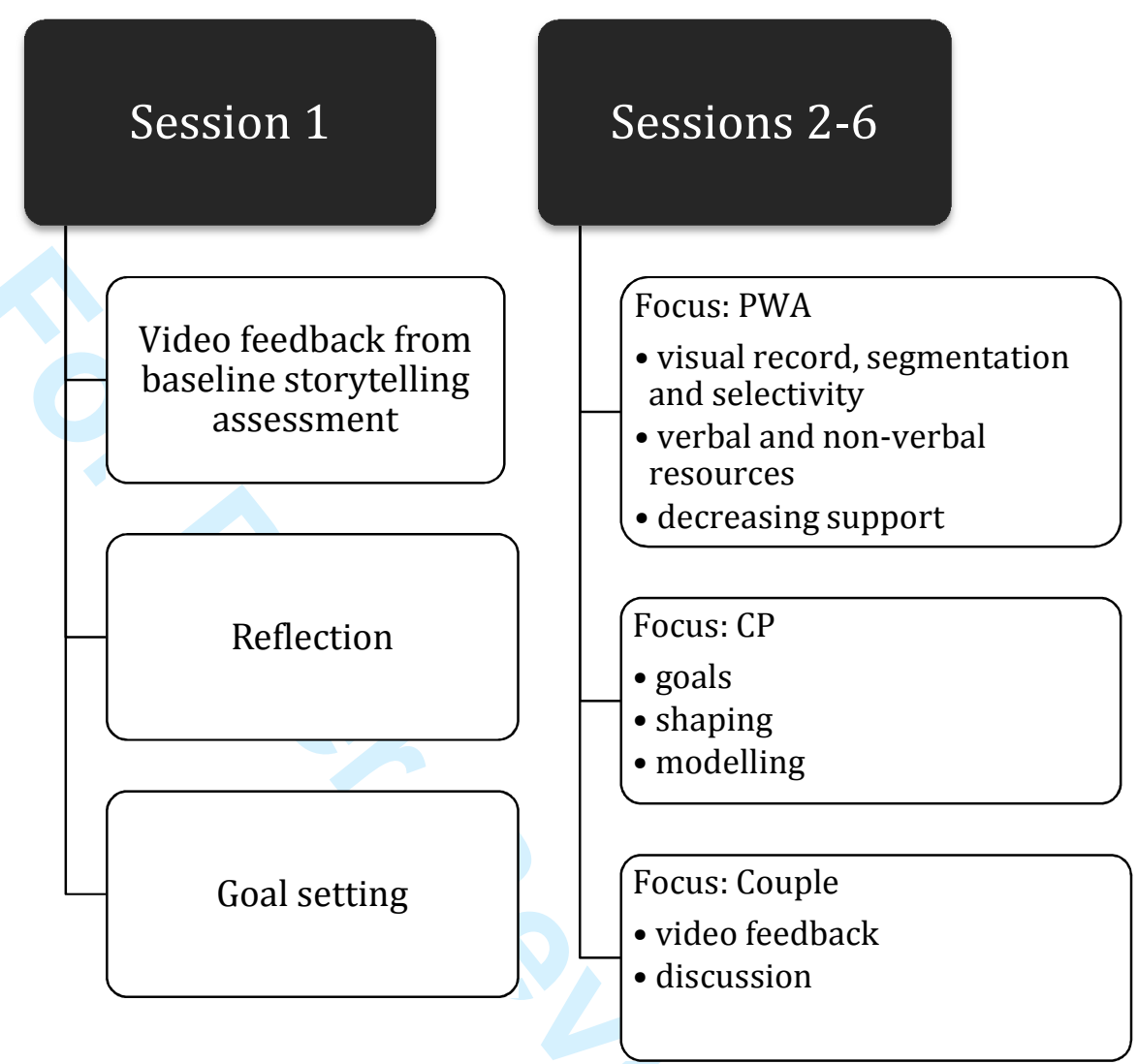
Figure 2: Changes in Peter's contribution to storytelling across four broad categories pre- and post-therapy (proportional data)

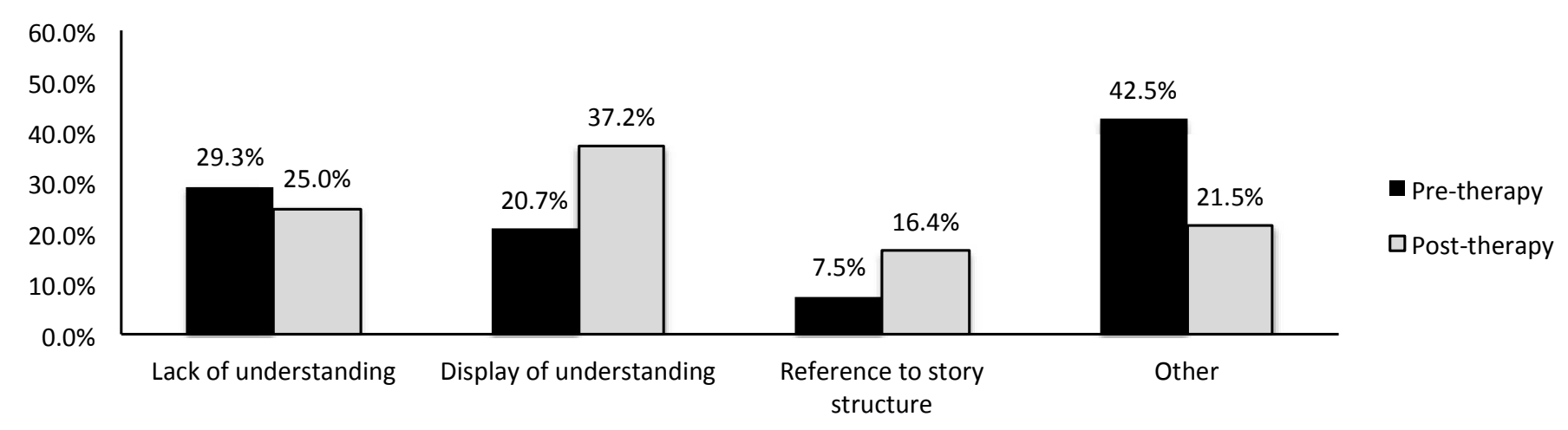


Figure 3: Analysis of Peter's specific behaviours in pre- and post-therapy narrative data

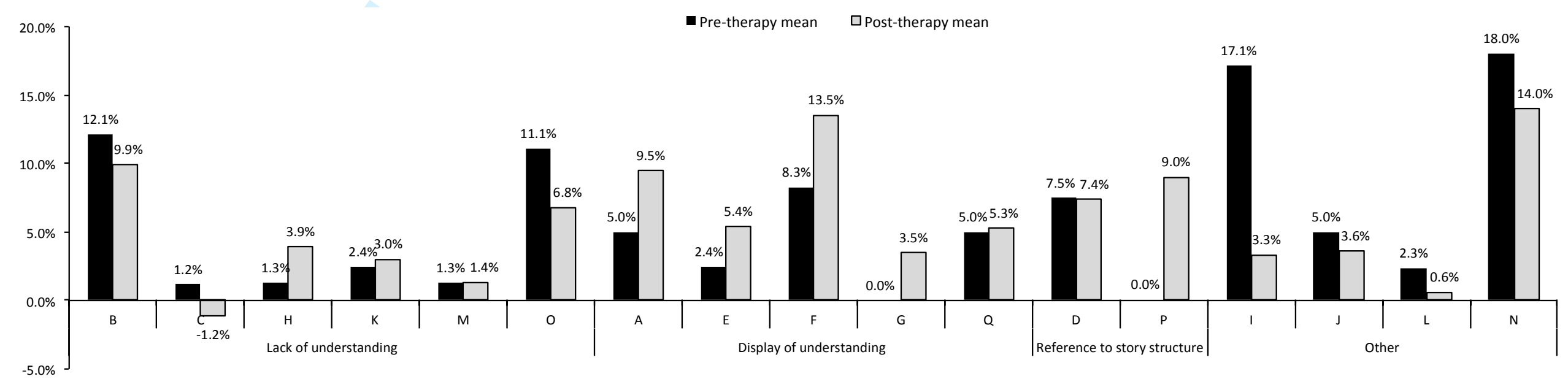

Key:

\begin{tabular}{|l|l|l|l|}
\hline \multicolumn{2}{|l|}{ Lack of understanding } & G: & display of understanding the humour of the story \\
\hline B: & other-initiated repair & Q: & explicit display of understanding \\
\hline C: & open class repair & Reference to story structure \\
\hline H: & 'do you mean' construction & D: & 'what happened next?' question \\
\hline K: & explicit display of understanding difficulty & P: & controlling the pace of storytelling \\
\hline M: & complaint as a form of other-initiated repair & Other \\
\hline O: & $\begin{array}{c}\text { checking question or checking for more } \\
\text { information }\end{array}$ & I: & passing turn \\
\hline Display of understanding & J: & acknowledgement of PWA's linguistic difficulties \\
\hline A: & reformulation & L: & test question \\
\hline E: & inference & N: & claim of understanding \\
\hline F: & summary & & \\
\hline
\end{tabular}

